\title{
THE EFFECT OF IRRIGATION WITH TREATED WASTEWATER ON SOME SOIL AND PLANT PROPERTIES.
}

\author{
T. A. Seaf Elnasr ${ }^{1}$, Atef.F.Ahmed ${ }^{2}$, M.A.El-Mottaleb ${ }^{3}$ and Ragab. E. M. Osman ${ }^{2}$ \\ ${ }^{1,3}$ Department of Chemistry, Faculty of Science Al-Azhar University, Assiut, 71524, Egypt \\ ${ }^{2}$ Soil, Water and Environment Research Institute, Agriculture Research Center, Cairo, Egypt. \\ Corresponding author E-mail address: tarekseaf@yahoo.com
}

\begin{abstract}
Today the use of municipal wastewater as alternative source of water for irrigation purpose is a common practice. Adsorption process has been found to be one of the most effective and economic method with high potential for removal and recovery of contaminants from wastewater. In this study the effect of irrigation with treated wastewater on plant and soil's chemical and physical properties is studied. The treatment of wastewater by adsorption onto nano Montmorillonite or Montmorillonite - Humic complex was carried out by using fixed bed column model. Total organic carbon, heavy metals, major cations and anions, EC, and pH were determined before and after treatment process. Wastewater purification occurred with flow rate of $100 \mathrm{ml} / \mathrm{hour}$ for each $10 \mathrm{~g}$ nano Montmorillonite or Montmorillonite - Humic complex. Results showed that the Montmorillonite - Humic complex was much better in wastewater treatment than nano Montmorillonite where humic acid increased the total active and binding sites. Pot experiment were conducted to study the influence of irrigation with treated and non treated wastewater on yield and chemical composition of Faba Bean plant and soil's chemical and physical properties. Plant and soil analysis showed great changes in plant and soil properties after irrigation with treated wastewater than untreated due to significant reduction of heavy metals, total organic carbon, EC, total dissolved solids and $\mathrm{pH}$. The interesting outcome of this study is that treated wastewater is an effective source for irrigation. It is encouraging to reuse wastewater in agriculture system after full treatment.
\end{abstract}

Keywords : Polarization, EIS, Electrochemical, Steel, Corrosion, Acid inhibition

\section{INTRODUCTION}

Egypt is an arid country facing challenges due to its limited water resources. Non conventional sources exist to meet part of the country's water requirements. Agriculture is the largest water consumer in Egypt with its share exceeding $80-85 \%$ of the total demand for water. Sustainable agriculture strongly depends on the country's ability to conserve and manage its water resources. Shortage of irrigation water sources in Egypt brings out the issue of managing all the available water resources and to re-use the non-conventional water resources such as the reuse of agriculture drainage water and wastewater. Wastewater possesses have different biological, physical and chemical effects on the environment. In order to apply the wastewater for irrigation it should obtain the certain criteria of qualification after treatment, for parameters such as electrical conductivity (EC), heavy metals, total dissolved solids (TDS) and organic matters are also other parameters, which might be considered before application of wastewater to agricultural Soil. The principal processes which affect the physical properties of the soil by using the wastewater are the salt contents and the suspended solid [1].

One such a beneficial and successful procedure that has been in use is the purification of wastewater using natural and modified adsorbents. Several natural adsorbents are being used for treatment of contaminated wastewater and its sources. When a comparison is made with other low cost adsorbents, the clays and their modified composites have been found to be either better or equivalent in contaminant adsorption capacity from water. Clay minerals: Montmorillonite, Kaolinite, and Illite are widely used because of their high specific surface area, chemical and mechanical stability, a variety of surface and structural properties, and low cost which is 20 times cheaper [2] and remove approximately $70 \%$ of 
the waste of water in a water removal system than activated carbon [3] therefore clays play an important role in the environment by acting as a natural scavenger of pollutants by taking up cations and anions either through ion exchange or adsorption or both. Thus, clays invariably contain exchangeable cations and anions held to the surface. The edges and the faces of clay particles can adsorb anions, cations, nonionic and polar contaminants from waste water. The contaminants accumulate on clay surface leading to their immobilization through the processes of ion exchange, coordination, or ion-dipole interactions [2].

Clays have received attention as excellent adsorbents of $\mathrm{Cd}, \mathrm{Cr}, \mathrm{Co}, \mathrm{Cu}, \mathrm{Fe}, \mathrm{Pb}, \mathrm{Mn}, \mathrm{Ni}$, $\mathrm{B}$, As and zinc in their ionic forms from aqueous medium. The adsorption capacities differs from metal to metal and also depend on the type of clay used [5].

Montmorillonite and its modified forms have much higher metal adsorption capacity compared to that of kaolinite and its modified forms. Their work reports the successful and improved adsorption of metals [3]. Clays and humic substances most commonly exist in natural soils as clay-humic complexes [6]. Humic substances carry a huge variety of functional groups, with the majority being carboxylic $(-\mathrm{COOH})$ and phenolic $(\mathrm{OH})$ groups. These groups are believed to be the most active adsorption sites [7]. Accordingly these groups are believed to be the most active adsorption sites and are important for modeling the geochemical fate and biological availability of nutrients and pollutants in soils and aquatic environments [7].

Accordingly, the aim of this work is

1- The investigation of Nano Montmorillonite and the adsorption of humic acid onto Nano Montmorillonite under various solution conditions (ionic strength, $\mathrm{pH}$, and concentration of cations) for purification of wastewater.

2-The role of modified clay onto removing of heavy metals and organic contaminants from wastewater.
3-Study the effect of using treated and untreated wastewater on chemical and physical properties of soil.

\section{MATERIALS AND METHODS}

\section{Wastewater sampling}

Sewage wastewater was collected from Sohag governorate Egypt. Complete chemical analysis of wastewater :EC, $\mathrm{pH}$, Total organic carbon (TOC) , heavy metals, Pathogens, Major cations and major anions before and after treatment process were determined according to the methods adopted by Rainwater and Thatcher [8], Fishman and Friedman [9]. and American Society for Testing and Materials [8].

\section{Montmorillonite}

Montmorillonite is commonly abundant mineral in soils, was purchased from the source clay minerals Repository, Egyptian Petroleum Research Center for using in this study. Montmorillonite fraction was sieved to $80 \mathrm{~nm}$ diameter particles.

\section{Humic acid}

Humate salt was obtained from SigmaAldrich. Humate salt was used to prepare humic acid as follows [11]: humate salt has been dissolved in deionized water using sodium hydroxide (5M), and precipitated by acidification to a $\mathrm{pH}$ of 2 . The precipitate was redissolved in deionized water. This precipitation and dissolution were repeated 10 times. This pretreatment procedure could eliminate significantly the levels of other metals from HA, e.g. Al, Fe, Ca and Mg. humic acid was characterized by FT.IR spectra, elemental analysis and SEM.

\section{Preparation of nano Montmorillonite and humic acid stock solutions}

Montmorillonite suspensions ( $25 \mathrm{~g} \mathrm{~L}^{-1}$ ) stock solutions were prepared in order to obtain consistent solid concentrations in the equilibrium adsorption experiments. These suspensions were prepared in $0.01 \mathrm{~mol} \mathrm{dm}^{-3}$ of $\mathrm{KCl}$ for the HA adsorption at pH6 over a period of 14 days. Moreover the $\mathrm{pH}$ values checked up through the experimental life-time. Stock HA 
THE EFFECT OF IRRIGATION WITH TREATED WASTEWATER ...

solutions were prepared by dissolving HA in an aqueous solution of $\mathrm{NaOH}\left(0.1 \mathrm{~mol} \mathrm{dm}^{-3}\right)$ with shaking for $1 \mathrm{~h}$. $\mathrm{HCl}$ or $\mathrm{NaOH}$ was then added to adjust its $\mathrm{pH}$ to 6 . Amounts of $\mathrm{KCl}$ were added to HA solutions to adjust to the desired ionic strength $\left(0.01 \mathrm{~mol} \mathrm{dm}^{-3}\right)$. Finally humic acid concentration reached $416 \mathrm{mg} \mathrm{L}^{-1}$ in its stock solution [12].

\section{Soil samples}

Soil material was taken from the surface layer $(0-30 \mathrm{~cm})$ of an experimental farm, at Shandwell Agricultural Research station Sohag Governorate, Egypt. Physical and chemical analysis of soil such as mechanical analysis, $\mathrm{pH}$ value, calcium-carbonate content, organic matter, EC, soluble cations and anions were determined before and after irrigation with untreated and treated wastewater.

\section{Seeds}

Egyptian Faba bean seeds (Balady) was used in all experiments. These seeds were obtained from the Ministry of Agriculture.

\section{Preparation of modified Montmorillonite}

The Montmorillonite and humic acid stock solutions were prepared as described in previous study [13]. Then, Montmorillonite or Mon - HA or Montmorillonite complexes were resuspended for $24 \mathrm{~h}$ in the horizontal shaker. This washing step was repeated three times to exclude the free HA from the solution. The stock Mon or Mon-HA or Montmorillonite suspensions was stored over night and part of them has been freeze-dried and stored. The Montmorillonite or Mon-HA complex adsorbents were characterized using FT-IR spectroscopy, BET surface area and scan electron microscope (EDAX).

\section{Treatment of wastewater by adsorption on Mon-HA and Montmorillonite}

Treatment process was carried out with Montmorillonite or Mon-HA complex. The treatment of wastewater by adsorption process was carried on using fixed bed column model [12] .The Column has a diameter of $3 \mathrm{~cm}$ and
$30 \mathrm{~cm}$ length. The rate of adsorption process was detected every day.

\section{Experimental design}

A pot experiment was carried out to investigate the influence of treated and untreated wastewater on plant and soil's chemical and physical properties. Experiments were carried out at 2015 and 2016 years. Pots were filled with $350 \mathrm{~g}$ of soil sample. Then, seeds were planted in pots. Untreated and treated wastewaters have been added to pots from stock water during planting. The pots were well arranged in a complete block with three replicates and placed on an open plastic mist bench. Plants were irrigated using the same volume of water in each time during the experiment. Throughout the harvest period; the vegetative growth, yield and concentrations of chlorophyll (a) and (b) were determined as outlined by Witham [14].

\section{RESULTS AND DISCUSSION}

\subsection{Properties of humic acid, Montmorillonite and Montmorillonite - humic complex.}

Elemental analysis is one of most and important means of characterizing HA [15]. The elemental analysis result for the Aldrich HA was 40.06, 4.57, 0.79, 0.73 and 53.83 for carbon, hydrogen, nitrogen, sulphur and oxygen percentage respectively.

Energy Disperse Analysis X-ray (EDAX) results show chemical composition analysis of Montmorillonite (O 70.47\%, Fe 1.03\%, Mg $1.68 \%$, Al 6.07\%, Si 14.45\%, K 3.85\%, Ca $1.03 \%$, S 3.85\%).

Figure.(1) displays the EDAX chart of Montmorillonite. The elemental analysis for Montmorillonite explains that $\mathrm{Si}: \mathrm{Al}$ is with a ratio of 2:1 approximately, and the structure is comprised of an octahedral aluminum layer overlying a tetrahedral silicon sheet.

Figure 2 showed FTIR spectra of humic acid, Montmorillonite and Montmorillonite humic complex. A large peak was observed at 
$1640-1588 \mathrm{~cm}^{-1}$, associated with the carbonyl of the carboxylic acid group, and a broad peak at $3416.6 \mathrm{~cm}^{-1}$, associated with carboxylates, phenols, and alcohols, for humic acid while the spectrum of Montmorillonite is a typical spectrum for well-crystallized Montmorillonite and matches the literature data very well [16] as follows: a band around $3689 \mathrm{~cm}^{-1}$ and 3629 major changes of absorbance band at 16401588 and $1383 \mathrm{~cm}^{-1}$ as compared with spectrum of the HA. These bands are characteristic of protonated, ionic and complexed carboxylic groups [17]. These bands shift to lower frequency and broadening of the doublet that includes the latter feature, and changes in the region below $1020 \mathrm{~cm}^{-1}$. These effects indicate that sorption on

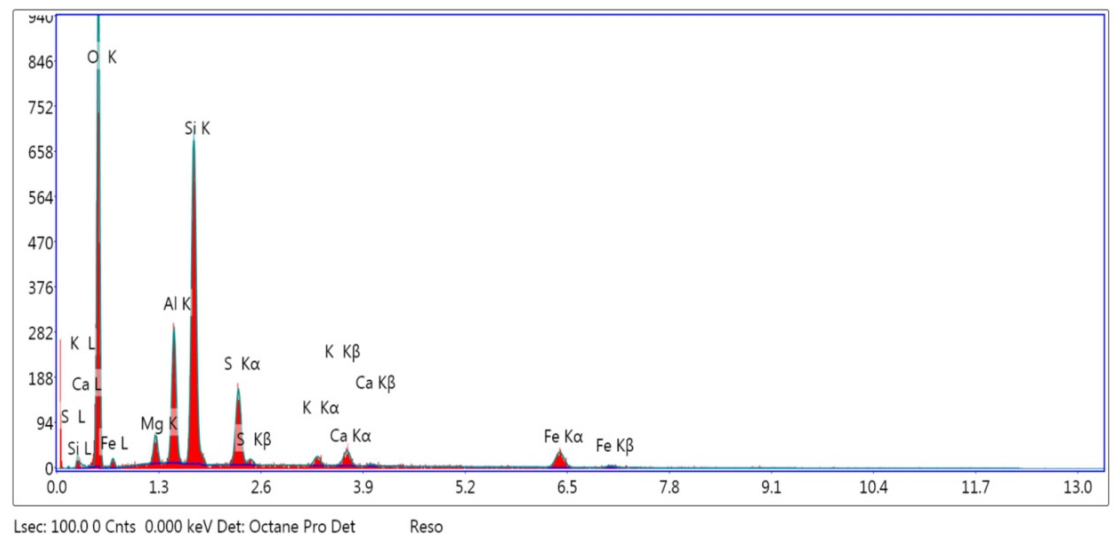

Fig .1. Elemental analysis by EDAX

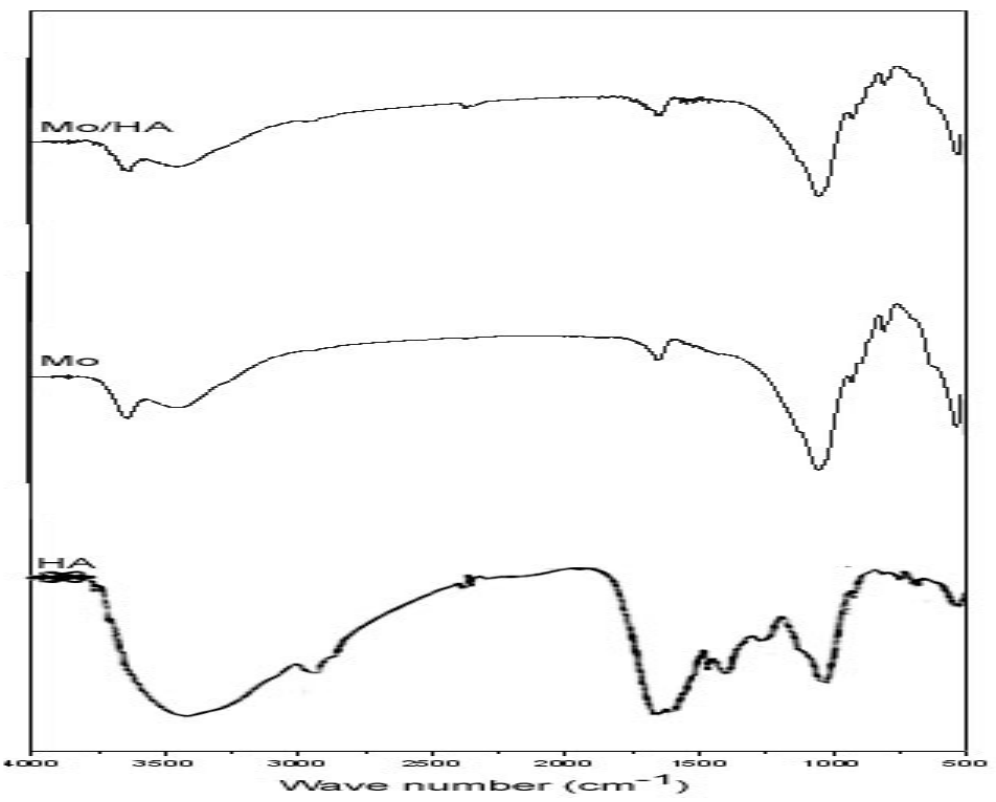

Fig.2. FT-IR spectra of the humic acid, Montmorillonite and Montmorillonite - HA complex.

$\mathrm{cm}^{-1}$ due to $\mathrm{OH}$ stretching of inner hydroxyl groups and the strong bands at 1097 and 1026 $\mathrm{cm}^{-1}$, indicates perpendicular and in-plane $\mathrm{Si}-\mathrm{O}$ stretching. In addition, FT-IR spectroscopic of Montmorillonite - humic acid complex showed
Montmorillonite carried out through $\mathrm{COO}^{-}$ functional groups (20). This considers strong evidence for ligand-exchange mechanism. 


\section{Scanning electron microscopy}
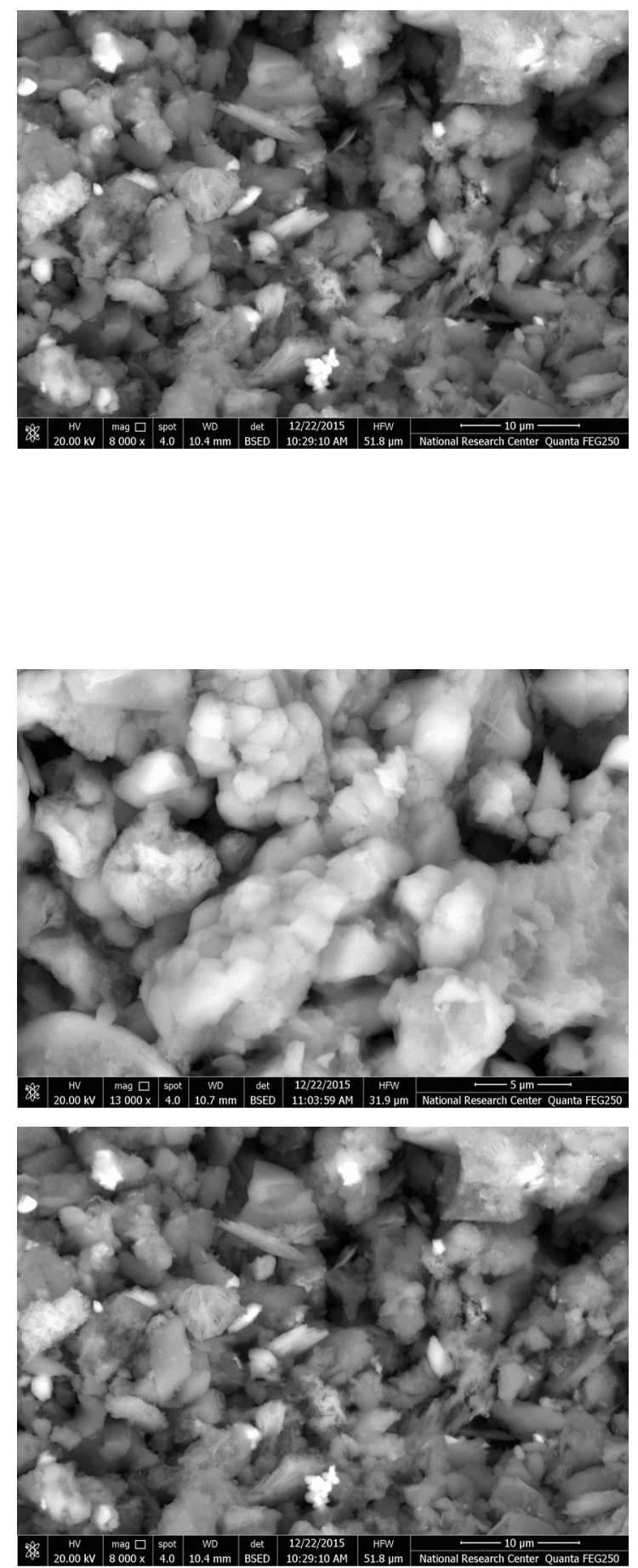

Fig. 3. SEM photograph of (a) HA, (b) Mon and (c) Mon-HA complex

The scanning electron microscopy (SEM) was used to investigate the morphology changes with adsorption of HA. The SEM of HA, Montmorillonite and Montmorillonite humic complex revealed numerous small discrete particles scattered among the micro aggregate. It was found that the Montmorillonite - humic complex has rough surface. These indicated that humic acid do aggregation for Montmorillonite particles.

In order to investigate the influence of humic acid on the surface, BET surface area for Montmorillonite and Montmorillonite - humic acid complex was determined. BET surface of Montmorillonite and Montmorillonite - humic acid complex were 35.2 and $47.4 \mathrm{~m}^{2} \mathrm{~g}^{-1}$ respectively. Therefore, humic acid enhanced the surface and increased the active site of Montmorillonite.

The second way for evaluation the effect of humic acid on Montmorillonite surface, total active site for Montmorillonite and Montmorillonite - humic complex were determined by conduct metric method [18]. Cleary, total active sites on Montmorillonite humic complex was $6.2 \mathrm{meq} \mathrm{g}^{-1}$ while on Montmorillonite was $5.71 \mathrm{meq} \mathrm{g}^{-1}$. This refers to a greater functional groups $(-\mathrm{COOH},-\mathrm{C}=\mathrm{O})$ and $-\mathrm{OH}$ ) on humic acid than that on Montmorillonite at the same conditions. Also the results of total active sites on Montmorillonite humic acid complexes have been matched BET surface area.

\section{Wastewater treatment}

Treatment of wastewater carried out by adsorption onto two sorbents "Montmorillonite and Montmorillonite humic acid complex" by using fixed bed column model. The rate flow of this process was $100 \mathrm{ml} /$ hour for each 10 grams Montmorillonite or Montmorillonite - humic acid. From the results in Table.1.it obvious that Montmorillonite - humic acid better than Montmorillonite in treatment wastewater from heavy metals and organic contaminates. This refers to highly active site contents and BET surface area of Montmorillonite - humic acid complex than Montmorillonite. Moreover, humic acid generally contains both hydrophobic and hydrophilic moieties as well as many functional groups $(-\mathrm{COOH},-\mathrm{C}=\mathrm{O}$, and $-\mathrm{OH}$ ) bonded to the aliphatic or aromatic carbons in the macromolecules. For that, humic 
acid can reacts with inorganic and organic contaminates. Thereafter, hydrophobic fraction of humic acid interacts with organic contaminates by hydrophobic - hydrophobic interaction mechanism while carboxylic and hydroxyl group interact with heavy metals by electrostatic and complexation mechanisms.

By the same way, Montmorillonite - humic acid complex enhanced chemical analysis (EC, $\mathrm{pH}$, major cations and major anions) of wastewater than Montmorillonite. The Ec and $\mathrm{pH}$ values became much better to use in irrigation process. In addition, the ratio of cations and anions highly effected with treatment by Montmorillonite - humic acid complex than Montmorillonite. Wheresoever's, humic acid act as cheating agent.

Pathogen analysis was determined for wastewater before treatment. Pathogen analysis result showed that there was one type of fungi call aspergillas sp and two types from bacteria negative and positive bacteria. For that, drops of chloride were added to wastewater before treatment. Pathogen analysis has been repeated again after treatment and the results showed that treated wastewater became free from fungi and bacteria.

\section{Effect of applied treated and untreated wastewater in irrigation}

In order to evaluate the influence of irrigation with treated and untreated waste water on some plant and soil properties under pots experiment. Faba bean seeds were sown in pots and under different irrigation with untreated and treated wastewater by Montmorillonite and Montmorillonite - humic complex in three replicated.

Table 1: Chemical analysis (heavy metals and organic matter) of treated wastewater

\begin{tabular}{|c|c|c|c|c|c|c|c|c|c|}
\hline Sample & $\begin{array}{c}\mathrm{Cd}^{2+} \\
\mathrm{ppm}\end{array}$ & $\begin{array}{c}\mathrm{Fe}^{2+} \\
\mathrm{ppm}\end{array}$ & $\begin{array}{c}\mathrm{Zn}^{2+} \\
\mathrm{ppm}\end{array}$ & $\begin{array}{c}\mathrm{Cu}^{2+} \\
\mathrm{ppm}\end{array}$ & $\begin{array}{c}\mathrm{Mn}^{2+} \\
\mathrm{Ppm}\end{array}$ & $\begin{array}{c}\mathrm{Co}^{+} \\
\mathrm{ppm}\end{array}$ & $\begin{array}{c}\mathrm{Cr}^{6+} \\
\mathrm{ppm}\end{array}$ & $\begin{array}{c}\mathrm{Se}^{4+} \\
\mathrm{Ppm}\end{array}$ & $\begin{array}{c}\mathrm{Pb}^{2+} \\
\mathrm{ppm}\end{array}$ \\
\hline Untreated WW & 0.16 & 0.33 & 0.09 & 0.002 & 0.003 & 0.079 & 0.019 & 4.030 & 0.054 \\
\hline $\begin{array}{c}\text { Treated WW } \\
\text { with Mon }\end{array}$ & 0.0002 & 0.002 & 0.011 & 0.001 & 0 & 0 & 0.0022 & 2.60 & 0 \\
\hline $\begin{array}{c}\text { Treated WW } \\
\text { with Mon -HA } \\
\text { complex }\end{array}$ & 0 & 0.002 & 0.005 & 0 & 0 & 0 & 0 & 1.94 & 0 \\
\hline
\end{tabular}

Table 2: Chemical analysis (cations and anions) of treated and un treated wastewater

\begin{tabular}{|c|c|c|c|c|c|c|c|c|c|c|}
\hline Sample no & $\mathrm{pH}$ & $\begin{array}{c}\mathrm{EC} \\
\mathrm{ppm}\end{array}$ & $\begin{array}{c}\mathrm{Na}^{+} \\
\mathrm{ppm}\end{array}$ & $\begin{array}{c}\mathrm{K}^{+} \\
\mathrm{ppm}\end{array}$ & $\begin{array}{c}\mathrm{Ca}^{2+} \\
\mathrm{ppm}\end{array}$ & $\begin{array}{c}\mathrm{Mg}^{2+} \\
\mathrm{ppm}\end{array}$ & $\begin{array}{c}\mathrm{Cl}^{-} \\
\mathrm{ppm}\end{array}$ & $\begin{array}{c}\mathrm{SO}_{4}^{2-} \\
\mathrm{ppm}\end{array}$ & $\begin{array}{c}\mathrm{NO}_{3}^{-} \\
\mathrm{ppm}\end{array}$ & $\begin{array}{c}\mathrm{HCO}_{3}^{-} \\
\mathrm{ppm}\end{array}$ \\
\hline Untreated WW & 8.3 & 1030 & 80.87 & 40.65 & 55.28 & 70.79 & 74.00 & 40.3 & 24.65 & 136.32 \\
\hline $\begin{array}{c}\text { Treated WW } \\
\text { with } \\
\text { Montmorillonite }\end{array}$ & 8.00 & 720 & 61.63 & 25.02 & 24.37 & 40.41 & 42.73 & 30.71 & 18.32 & 95.43 \\
\hline $\begin{array}{c}\text { Treated WW } \\
\text { with Mon-HA } \\
\text { complex }\end{array}$ & 7.6 & 620 & 50.80 & 19.63 & 20.13 & 28.23 & 20.5 & 22.8 & 14.25 & 60.58 \\
\hline
\end{tabular}


THE EFFECT OF IRRIGATION WITH TREATED WASTEWATER ...

Table.3. Chemical Analysis for soil samples under study (in the peast extractable)

\begin{tabular}{|c|c|c|c|c|c|c|c|c|c|c|}
\hline \multirow{2}{*}{ Soil samples } & \multirow{2}{*}{$\begin{array}{c}\mathrm{pH} \\
1: 2.5\end{array}$} & \multirow{2}{*}{$\begin{array}{c}\text { EC } \\
\mathrm{ds} / \mathrm{m}\end{array}$} & \multicolumn{4}{|c|}{ Cations me/L } & \multicolumn{4}{|c|}{ Anions me/L } \\
\hline & & & $\mathrm{Ca}^{2+}$ & $\mathrm{Mg}^{2+}$ & $\mathrm{Na}^{+}$ & $\mathrm{K}^{+}$ & $\mathrm{CO}_{3}{ }^{2-}$ & $\mathrm{HCO}_{3}^{-}$ & $\mathrm{Cl}^{-}$ & $\mathrm{SO}_{4}{ }^{2-}$ \\
\hline Blank & 7.90 & 1.02 & 8.69 & 0.78 & 0.82 & 0.25 & - & 4.25 & 5 & 2.30 \\
\hline Untreated WW & 8.3 & 1.3 & 8.62 & 1.3 & 3.93 & 0.26 & - & 4.80 & 4.69 & 2.98 \\
\hline $\begin{array}{c}\text { Treated WW } \\
\text { with Mon }\end{array}$ & 7.70 & 0.8 & 6.3 & 1.00 & 2.93 & 0.15 & - & 4.01 & 3.33 & 1.62 \\
\hline $\begin{array}{c}\text { Treated WW } \\
\text { with Mon-Ha } \\
\text { complex }\end{array}$ & 7.60 & 0.67 & 4.8 & 0.82 & 2.01 & 0.10 & - & 3.66 & 3.02 & 1.07 \\
\hline
\end{tabular}

Table 4: Physical Analysis for soil samples under investigation

\begin{tabular}{|c|c|c|c|c|c|c|}
\hline \multirow[b]{2}{*}{ Treatment } & \multirow{2}{*}{$\begin{array}{c}\mathrm{SP} \\
\mathrm{mL} / 100 \mathrm{~g}\end{array}$} & \multirow{2}{*}{ OM\% } & \multicolumn{3}{|c|}{ Mechanical Analysis } & \multirow{2}{*}{$\begin{array}{l}\text { Texture } \\
\text { class }\end{array}$} \\
\hline & & & Clay\% & Silt\% & Sand & \\
\hline Blank & 48 & 0.81 & 20.6 & 57 & 22.4 & $\begin{array}{c}\text { Silt } \\
\text { Loam }\end{array}$ \\
\hline Untreated WW & 45 & 0.7 & 20.6 & 57 & 22.4 & $\begin{array}{c}\text { Silt } \\
\text { Loam }\end{array}$ \\
\hline $\begin{array}{l}\text { treated WW with } \\
\text { Montmorillonite }\end{array}$ & 48 & 0.3 & 20.6 & 57 & 22.4 & $\begin{array}{l}\text { Silt } \\
\text { Loam }\end{array}$ \\
\hline $\begin{array}{l}\text { treated WW with Mon } \\
\text {-Ha complex }\end{array}$ & 45 & 0.15 & 20.6 & 57 & 22.4 & $\begin{array}{c}\text { Silt } \\
\text { Loam }\end{array}$ \\
\hline
\end{tabular}

\section{Soil properties}

Data in table 3 and 4 showed the change in physical and chemical of soil properties before and after irrigation by treated and untreated wastewater. The results illustrated that little bite increasing in organic matter contents and saturation percentage "of table 3" in case of using untreated than treated wastewater. These results refers to removing of organic contaminates during treatment process [19].

Table.4. explained that irrigation with untreated wastewater caused increasing in EC, $\mathrm{pH}$ and major cations and anions while EC, $\mathrm{pH}$ and major cations and anions decreased after irrigation with treated wastewater by Montmorillonite or Mon- humic complex. In addition, soil chemical properties became much better after irrigation with treated wastewater by Montmorillonite - humic complex than Montmorillonite. Hence irrigation with treated wastewater by Montmorillonite - humic complex enhanced the soil chemical and physical properties.

Plant properties

Effect of irrigation with treated and untreated wastewater on Faba bean properties

Means of Vegetative Growth Characters of Faba bean ; leaf area $\left(\mathrm{cm}^{2}\right)$ Stem diameter, plant height (cm), number of leaves per plant, plant fresh weight(g), plant dry weight $(\mathrm{g})$, number of branches per plant, leaf fresh weight and leaf dry weight under treated and untreated WW are presented in Table.5.The results showed that plant height, Relative water content, Chlorophyll a, Chlorophyll b and Carotenoids parameters measured were significantly affected by the different water treatment, while No of leaves, Branches, Leaf width, Root length and Leaf area of plot were insignificantly affected. 
Table 5: Vegetative Growth Characters of Faba bean

\begin{tabular}{|c|c|c|c|c|c|c|c|c|c|c|c|c|}
\hline Treatment & $\begin{array}{l}\text { Plant } \\
\text { heigh } \\
\text { t } \\
(\mathrm{cm})\end{array}$ & $\begin{array}{c}\text { Relat } \\
\text { ive } \\
\text { water } \\
\text { conte } \\
\text { nt } \% \\
\end{array}$ & $\begin{array}{c}\text { Chlorop } \\
\text { hyll a } \\
(\mu g / m l(\end{array}$ & $\begin{array}{c}\text { Chlorop } \\
\text { hyll } \\
\text { b( } \mu \mathrm{g} / \mathrm{ml} \\
\mathbf{l}\end{array}$ & $\begin{array}{c}\text { Caroten } \\
\text { oids }(\mu \mathrm{g} / \\
\mathrm{ml} /\end{array}$ & $\begin{array}{c}\text { dry } \\
\text { weight } \\
\text { (g) }\end{array}$ & $\begin{array}{l}\text { fresh } \\
\text { weight } \\
\text { (g) }\end{array}$ & $\begin{array}{l}\text { No of } \\
\text { leaves }\end{array}$ & $\begin{array}{l}\text { No of } \\
\text { Branch } \\
\text { es }\end{array}$ & $\begin{array}{c}\text { Leaf } \\
\text { width ) } \\
\text { (m)) }\end{array}$ & $\begin{array}{c}\text { Root } \\
\text { length } \\
\text { (cm) }\end{array}$ & $\begin{array}{c}\text { Averag } \\
\text { e leaf } \\
\text { area of } \\
\text { pot } \\
\text { (cm) }\end{array}$ \\
\hline $\begin{array}{c}\text { Untreated WW } \\
\text { S1 }\end{array}$ & 12.00 & 58.9 & 10.1 & 19.2 & 0.8852 & 0.0679 & 0.40 & 6.00 & 4.3 & 1.9 & 4.33 & 143.45 \\
\hline $\begin{array}{c}\text { Treated WW } \\
\text { with } \\
\text { Montmorillonit } \\
\text { e } \\
\text { S2 } \\
\end{array}$ & 17.67 & 67.8 & 17.1 & 29.3 & 4.83 & 0.0887 & 0.597 & 8.00 & 6.3 & 3.0 & 4.17 & 165.14 \\
\hline $\begin{array}{c}\text { treated WW } \\
\text { with Mon-HA } \\
\text { complex } \\
\text { S3 } \\
\end{array}$ & 23.50 & 73.95 & 21.9 & 38.31 & 8.678 & 0.134 & 0.573 & 9.00 & 7.1 & 4.1 & 5.33 & 177.89 \\
\hline
\end{tabular}

\section{Vegetative Growth Characters}

\section{Plant height}

The results of Faba bean plant height indicated significant differences among plant height between S3and S1 treatments and between S2 and S1 treatments. Data of plant height indicated that $\mathrm{S} 2$ achieved the highest values of plant height $(23.50 \mathrm{~cm})$, while plant height was most significantly depressed at application of S1 $(12.00 \mathrm{~cm})$ [20].

\section{Relative water content (RWC)}

The results indicated that relative water content was significantly affected by S3 treatment. The data computed for the relative water content showed that the highest values of relative water content were (73.95 \%) at S3, using wastewater treated with Mon- Ha complex. While, lowest values of relative water content were (58.9\%) at S1 using Untreated wastewater [21].

\section{Photosynthetic pigments}

\section{Chlorophyll a}

The values of Chlorophyll a of C. Faba bean are presented in Table. The comparsons among the various treatment combinations showed that S2, significantly, gave the highest mean values for Chlorophyll a while values were most significantly depressed at application of S1. Significant difference was observed in Chlorophyll a between S3, S2 and between S2, S1.

\section{Chlorophyll b}

The values of Chlorophyll b of C. Faba bean are presented in Table. The comparisons among the various treatment combinations showed that S2, significantly, gave the highest mean values for Chlorophyll b while values was most significantly depressed at application of S1. Significant difference was observed in Chlorophyll a between S3, S2 and between S2, S1 [22].

\section{Carotenoid}

The comparisons among the various treatment combinations showed that S3, significantly, gave the highest mean values for Carotenoid. Significant difference was observed in Carotenoid between S3, S2 and between S3, S1. [23].

\section{CONCLUSION}

The comparisons among the mean values of the studied vegetative traits, generally, indicated that the highest mean values were gained as a result of treated waste water with Mon-Ha complex application. Such a noticed positive effect of treated water on vegetative growth characters and Photosynthetic pigments could be due to that the available amounts of macro and micro-elements of plants in the soil were relatively low/high, as appeared from the results of soil analyses of the used experimental sites (Table1, 2).

In conclusion, the present investigation demonstrated the validity of producing Faba 
THE EFFECT OF IRRIGATION WITH TREATED WASTEWATER ...

bean using wastewater treated with Mon -Ha complex. Such treatment combination will decrease the pollution of environment as well as insures safe food.

\section{REFRENCES}

[1] J. Abedi-Koupai, B. Mostafazadeh-Fard, M. Afyuni, M.R. Bagheri , College of Agriculture, Isfahan University of Technology, Isfahan, Iran PLANT SOIL ENVIRON., 52, (8): 335-344 , (2006).

[2] Rajani Srinivasan Advances in Materials Science and Engineering, Volume, 872531, 17, (2011).

[3] R. M. Zakaria, I. Hassan, M. Z. El-Abd and Y. A. El-Tawil, IWTC 13, Hurghada, Egypt ,(2009).

[4] Nwabanne, J.

$\mathrm{T}$. and igbokwe, P. K, Int. J. Environ. Res, 6 (4) 945952, (2012).

[5] Syafalni, Rohana Abdullah, Ismail Abustan, Aimi Nadiah Mohd Ibrahim, 4 (3)379-391 (2013).

[6] Jutta Renate V eronika Pils, Iowa State University, Msc, Iowa State University,( 2005).

[7] Mohamed Eid Abdel-Hamid El-Sayed, Influence of Humic Acid on the Sorption of Heavy Metal Cations on Clay, Egypt. Ms.C, thesis, Minia University,( 2009).

[8] Rainwater, F.H. and L.L. Thatcher, 1960. U.S. Geol. Survey, Water Supply. Paper No.1454, U.S.A., p: 301.

[9] Fishman, M.J. and L.C. Friedman, 1985. U.S. Geol. Surv., Book 5, Chapter A1. Open File Report, pp.85-495, Denver, Colorado, U.S.A.

[10] American Society for Testing and Materials (ASTM), 2002: "Water and environmental technology”. Annual book of ASTM standards, U.S.A., Sec. 11, Vol.11.01, and 11.02, West Conshohocken.

[11] Swift R. S. In: Methods of Soil Analysis: Part 3, Chemical Methods. Sparks, D. L.; Bartels, J. M.; Bigham, J. M. (Eds.), Soil Sci. Soc. Of America. Madison, WI; 1996; p. 1018.

[12] Zanaty R. Komy, Ali M. Shaker, Said E.M.Heggy, Mohamed E.A. El-Sayed, Chemosphere 99(2014)117 124/10.1016/ 2013.10.048).

[13] Shaker, A., Komy, Z., Heggy, S., El-Sayed, M., 2012. J. Phys. Chem. A 116, 10889-10896.
[14] Department of Chemical Engineering, Nnamdi Azikiwe University, P.M.B. 5025, Awka, Nigeria, Int. J. Environ. Res., 6(4):945-952, Autumn 2012: 1735-6865.

[15] S. A. Visser, Water Res., 17, 1393, (1983).

[16] Y-P. Chin, G. Aiken and E. O’Loughlin, Environ. Sci. Technol., 28, 1853, (1994).

[17] M. A. Wilson, P. F. Barron and A. H. Gillan, Geochem. Cosmochimm Acta, 45, 1743, (1981).

[18] K. A. Throne, Humic Substances in the Sueuanne River, Georgia; In: R.G. Avertt, J.A. Leenheer, D.M. McKnight, K.A. Throne (Eds.), US Geological Survey Open-File Report 87557, Colorado, p. 251, (1989).

[19] A. Wild, Soils and The Environment, Cambridge university press. pp.190-204, (1993).

[20] Abid, M., S. Ahmad, M. K. Bilal and R.A. Wajid. Int. J. Agri. Biol. 4: 311-314, (2002).

[21] Olusegun Areola,Oagile Dikinya,Larona mosime,The African journal of plant scince and Biotechnology ,May (2010).

[22] Chen.W, Hou, Z \&Wu, L., Liang, Y and Wei, C. (2008).Plant Soil 326:61-73, (2010).

[23] Haq, I. U. Genetic Basis of Variation for Salinity Tol; erance in Okra (AbelmoschusesculentusL.). University of Agriculture Faisalabad, Pakitan, (2009). 
